\title{
THE TYPE OF SILENE BANKSIA (CARYOPHYLLACEAE)
}

\author{
D.J. MABBERLEY \\ Nationaal Herbarium Nederland, Universiteit Leiden branch, P.O. Box 9514, 2300 RA Leiden, \\ The Netherlands; National Herbarium of New South Wales, Royal Botanic Gardens Sydney, \\ Mrs Macquaries Road, Sydney NSW 2000, Australia
}

\section{SUMMARY}

The holotype of Silene banksia (Meerb.) Mabb. is a sheet in Meerburg[h]'s herbarium in Leiden.

Key words: Silene banksia, Caryophyllaceae, holotype.

Silene banksia (Meerb.) Mabb. is an ancient garden plant long cultivated in China, where it was one of the 'Hundred Flowers' of 17th century Chinese painters, being illustrated as early as the 10th century by Xu Xi (Mabberley, 1999). It has been introduced to Europe from Japan as well as China a number of times and, until recently, it was known in the West as Lychnis $\times$ haageana Benary ex Lem. Its ultimate origins are still unclear though, and all names referred to the plant are based on cultivated material, almost all of it grown in Europe. This includes the type-giving name, Lychnis banksia Meerb. At the time my paper on the plant's intricate history and systematics was being written, no specimen associated with Nicolaas Meerburg[h] was available and so it was feared his (rather crude) published illustration might have to serve as iconotype.

Now the matter is rectified, as the holotype from Meerburg[h]'s own herbarium has been located, thanks to the help of Stans Kofman (L), in the historic herbaria in Leiden:

Silene banksia (Meerb.) Mabb. (1999) 253 q.v. for full synonymy.

Basionym: Agrostemma banksia Meerb. (1798) t. 28 [12, 'Agrostema']. - Type: Meerburg[h] s.n. [Leiden Acc. 899144-160] (holo L), cultivated [? at Hortus Botanicus, Leiden, The Netherlands], s.d.

Silene sinensis (Lour.) H. Ohashi \& H. Nakai (1996) 270, syn. nov., non S. chinensis Bosse (1829).

\section{REFERENCES}

Bosse, J.F.W. 1829. Vollständiges Handbuch der Blumengärtnerei. Verlage der Hahn'schen Hofbuchhandlung, Hannover.

Mabberley, D.J. 1999. Silene banksia (Caryophyllaceae), an ancient garden plant. Telopea 8: 249-256.

Meerburgh, N. 1798. Plantae Selectarum Icones Pictae. J. Meerburg, Leiden.

Ohashi, H. \& H. Nakai. 1996. New names for East Asia species of Silene L. (Caryophyllaceae). J. Jap. Bot. 71: 268-272. 